\title{
Probing into Copyright Infringement by Sampling: from USA to EU
}

\author{
Kamrul Faisal, (LL.M.)
}

University of Turku, Finland

URL:http://dx.doi.org/10.19044/elp.v6no1a3

\begin{abstract}
Sampling has become a part and parcel of the musical industry in the postmodern culture. With the booming of the hip-hop and electronic genre of music, sampling revolution has been brought to the industry which is responsible for the emergence of copyright infringement issues in both alleged and substantiated forms. Sampling founded its origin in the United States, where the legal system seemed to be efficient in dealing with the balancing of competing rights between the intellectual property right holders and the users of those respective properties. It took almost three decades to the US legal system to develop a cross and check mechanism or licensing model which checks the permissibility of sampling through its own established rules comprised of law, doctrines and case laws. Now, similar issues have been referred to the European Court of Justice by the German Federal Supreme Court to determine the probability of EU copyright law's allowing sampling. The question urges the enthusiasm of investigating the existing legal framework of the EU, prima facie, sought strong protection against the right holders to leave any room for permitting sampling. This paper particularly focused to show how the US Fair Use and de minimis fits to the EU legal frame to answer the derived questions asked by the German court to the ECJ which will pave the way of licensing mechanism for sampling in the EU.
\end{abstract}

Keywords: Sampling, fair use, de minimis, United States, Germany.

\section{Introduction:}

Sampling is a process through which the music composer derives one or more musical component from any pre-existing work and incorporates those with his own music creation and thus forms another musical work. The easiest way to explain music sampling is when a producer/musician uses a part of an already recorded song to make a new piece of music. ${ }^{36}$ Samples can be

36 See Wilson, S. R. (2002). 
of different forms such as instrument samples such as guitars, violin, piano and some others and also can be made through various means such as taking only bits, altering the sequences of the original work in accordance with the taste of the sampler.

The genre that is most well-known for using samples is Hip-Hop. It is also Hip-Hop that originally introduced the public to sampling. ${ }^{37}$ It all started in New York in the late 70's when DJ's started to mix songs during live performances. ${ }^{38}$ They isolated "breaks" which they supplied with talked over, transformed in rapping for the first time which occupies a specific portion of today's music market. However, this was not limited to live performances anymore as they started recorded it and used in different songs. One of the most famous and earliest is the song "Rapper's Delight" by the Sugarhill Gang who sampled Chic's song called "Le Freak". This song set the bar for the future of Hip-Hop and the way sampling became a large part of it. ${ }^{39}$

The reason of sampling might be to exercise free expression, show cultural diversity or laziness, reduction of costs, lack of resources. From commercial perspective it can be argued that there is a market which attracts this particular genre of music where customers are satisfied in what they hear rather to think how that has been produced. ${ }^{40}$

Sampling has become a phenomenon, subject to copyright disputes, especially in America where several cases have been ruled in court. ${ }^{41}$ American courts were sufficiently diligent to form a foundation for dealing these alleged copyright infringement issues. Ultimately, courts relied on different principles: substantial similarity, fair use, free use, bright line, de minimis and some others. Fortunately, German Federal Constitutional Court also came up with rationale judgment through correcting Federal Supreme Court's judgment in Metall auf Metall, Kraftwerk, et al. v. Moses Pelham, et $a l .{ }^{42}$ Scarcity of proper and exact legislation made the situation of every case more complicated and of course unpredictable since different copyright holders fight against each other for their lawful interest.

37 See Lessig, L. (2008).

38 Christiansson, Upphovsrätt och närliggande aspekter musiksamling cit., p. 14.

39 Johnson, Music Copyrights, cit., p. 137.

40 http://smallbusiness.chron.com/sampling-important-business-80416.html

41 For example, those that will be brought up in the thesis: Bridgeport Music, Inc. v. Dimension Films, 410 F.3d 792, 798 (6 $6^{\text {th }}$ Cir. 2005), Jarvis v. A \& M Records 827 F.Supp. 282 D.N.J.,1993. April 27, 1993 and Saregama India Ltd. v. Timothy Mosley et al., 687 F.Supp 2d 1325, (S.D.Fla 2009) [2009 BL 276875]Case No. 08-20373.

42 Decision of the German Supreme Court, 20th of November 2008, No. I ZR 112/06. 


\subsection{Purpose of the Study}

The paper tended to assess the applicability of the US Fair Use and de minimis in EU by the ECJ.

\subsection{Literature Review}

The very basics relating to the foundations of copyright law and limitations such as works in public domain, one-bit protection, protection excluded by statutes were not covered due to having limited space. Important laws: constitutional \& statutory provisions of both the US and Germany along with core case laws had been discussed for understanding the development and values of the court decisions.

Besides, books, online and offline journal articles, online newspapers specified in bibliography were reviewed.

\subsection{Methodology}

Interdisciplinary legal research, doctrinal research and comparative method were made to assess how different jurisdictions have taken the opportunity and tackled the threats imposed by technological advancement. It will evaluate the past, the present and the future regulatory framework assessing the scope and structure from the US to the EU legal framework.

\section{Conceptual Issues}

\subsection{Writer of a Composition, Publisher ${ }^{43}$, Sound Recording and Mechanical license}

A composition has two sets of rights: the writer's share and the publisher's share. As a songwriter, one own both writing and publishing shares, but can transfer rights in the publisher share through a publishing deal. Under a publishing deal, the publisher of the composition is granted certain rights, and is then authorized to issue licenses and collect royalties in respect of that composition.

For example, the Ed Sheeran song "Thinking Out Loud", was cowritten by Ed Sheeran. Ed Sheeran has entered into a publishing deal with Sony/ATV Music Publishing. Because of this, Sony/ATV is responsible for license and collect royalties and fees due in respect of your compositions and then account these royalties to you on a regular basis whether for film use, TV use, cover versions, etc.

A sound recording is the actual final recording of a song, a fixation of sound. It often goes by the name of 'master' from the old 'master tape' expression. The authors are the performing artist and record producer, who in

43 https://support.tunecore.com/hc/en-us/articles/115006689148-What-is-the-differencebetween-the-Publisher-and-Writer-of-a-composition- 
essence are therefore the owners. However, recordings are typically made in assignment of record labels, whom have negotiated deals with both the artist and producer in which they transfer ownership by mechanical license of their copyright to the label in exchange for royalty payments.

\subsection{Copyright in Music}

The first step is to understand the relevant copyright issues. There are generally three copyrights in a musical recording: ${ }^{44}$

1. Copyright in the musical work. This is generally owned by the musician who composed the song, or their music publisher;

2. Copyright in any lyrics. This may or may not be owned by the same person who owns the copyright in the musical works; and

3. Copyright in the sound recording of the musical work. This is generally owned by the person or company who paid for the recording, often the record company that released the sound recording.

In order to use legally use a copyrighted sample, you need to get permission from the copyright holders of that sample which depends on what you are sampling.

- If you're sampling a composition, then you solely need permission from the copyright holder of the composition (probably a publisher on behalf of the writers).

- If you're sampling a master, then you need permission from both the copyright holder of the composition (publisher on behalf of writer) and the sound recording (label or performing artist).

\subsection{Doctrines evolved to justify sampling from case laws}

In order to counter claims of copyright infringement, a sampling artist who is being confronted by the legitimate copyright holder can claim the sample is an independent fixation of music, that it is small enough to be de minimis, that the original artist does not "own" the sampled section, that the digital sampling constitutes a Fair Use of the original, or that the digital sampling was done in parody and therefore is a Fair Use. ${ }^{45}$

\section{Fair use}

The five exclusive rights of a copyrighted work are stated in the United States Federal Copyright Act of $1976 .{ }^{46}$ It states that apart from the copyright rules, fair use of a copyright protected work is allowed if it is for the purpose

44 https://cyber.harvard.edu/fallsem98/final_papers/Tada.html

45 Twentieth Century Music Corp. v. Aiken, 422 U.S. 151, 156 (1975). Hampel, S. (1992).

"Note: Are Samplers Getting a Bum Rap?: Copyright Infringement of Technological Creativity?” 559 University of Illinois Law Review.

46 Section 106, The United States Federal Copyright Act of 1976 (17 U.S.C). 
of comment or criticize the original work, news reporting, teaching, scholarship or research. ${ }^{47}$ Fair use is a judge made doctrine and the determination of fair use is done by a test. To determine fair use, one should consider the factors: if the purpose of the use is either commercial or nonprofit educational purpose, the nature of the copyrighted work, the amount and substantiality of the work used in relation to the copyrighted work as a whole, how the use effects the potential market or the value of the copyrighted work. ${ }^{48}$

\section{Free use}

Similar to fair use, free use is the translation used in the abovementioned Kraftwerk-case. The free use is stated in section 24 of the German Copyright Act, UrhG. The German free use allows a third party to use a protected work without prior consent by the creator. ${ }^{49}$ It "allows the creation of an independent work using someone else's creation without permission" 50 . Hence it is very similar to the American fair use since it is an exception or defence for a copyright infringement, but it is a narrower doctrine since it only allows transformative use of the protected work. ${ }^{51}$ Free use shall be determined ad hoc on a case-by-case basis. ${ }^{52}$

\section{De minimis}

De minimis is Latin for "of minimal things". 53 It is a doctrine stating that the court shall not care for too small a matter. This means matter at hand is so insignificant that acknowledging it would lack legal consequence. In a case of music sampling, de minimis is no infringement since it fails to reach the level of infringement at all. ${ }^{54}$ This doctrine had been used for decades as a justification of music samplings before different courts in both the United States and in Europe. In fact, it proved to one of the stable practices in the US for decades and already survived several generations.

\subsection{The Current System of Licensing for Samples}

Licenses for samples are needed from both the owners of the sound recording copyright and the owner of the copyright for the underlying musical work. ${ }^{55}$ The mechanical licensing for entire songs, which involves paying the

47 Section 107, 17 U.S.C.

48 Section 107 (1-4), 17 U.S.C.

49 Tracy, Reilly (2012).

50 Neimann, F and Mackert, L. (2013).

51 Tracy, Reilly (2012).

52 Tracy, Reilly (2012).

53 Fellmeth, A and Horwitz, M. (2009).

54 Blessing, D. S. (2004) and Sykes, J. (2006).

55 Website, http://www.demouniverse.com/osu/papers/sampling.htm. 
composition copyright owners for the right to re-record a song, is mostly handled by the Harry Fox Agency in the United States. ${ }^{56}$ The Harry Fox Agency keeps a small percentage and distributes the rest to the music publishers, who pay about half of their receipts to the songwriters. ${ }^{57}$ There is no compulsory system for sound recordings and no universal system for licensing the composition copyright for a song that is sampled. ASCAP, BMI and SESAC, the performance rights societies, collect fees from all the radio stations, television stations and nightclubs that play the song and divide the sum among the artists. ${ }^{58}$ Again, only the underlying composition copyright holders receive income from performance rights societies. Most artists who use a noticeable sample license the sample by paying either a flat fee or a royalty calculation based on the number of copies sold of the new work. ${ }^{59} \mathrm{~A}$ more popular song or artist demands a higher licensing fee, as when Puff Daddy sampled the Police's "Every Breath You Take” for his "I'll Be Missing You.” Fear of litigation substantiated by the case history makes this practice a necessity for most sampling artists. The artists shoulder almost all of the cost of this system, since record labels pass the cost of licensing on to the artist. This is peculiar because in effect, the record company is making the sampling artist pay to protect the record company from being sued. Furthermore, because the record company of the original artist almost always has the copyright, the original artist does not receive most of the licensing fee. ${ }^{60}$

\section{Copyright Laws Relating to Music and Case Laws}

\subsection{U.S. Copyright Legislation for Music}

U.S. copyright law has its origin in Article I Section 8 of the Constitution:

The Congress shall have the power...to promote the progress of science and useful arts, by securing for limited times to authors and inventors the exclusive right to their writings and discoveries. ${ }^{61}$

The 1910 U.S. Copyright Law did not sufficiently anticipate technological inventions like the jukebox, this early law did allow the copyright owner of a nondramatic musical composition to demand fees from

56 Passman, Donald S. (1997).

57 http:www.mp3.com/news/073.html

58 In 1998, The Supreme Court decided that the Kingsmen should receive the royalties from their 1963 recording of the song "Louie Louie" that Gusto Records and GML had been withholding. These were not royalties for the written song, but rather the accumulation performance royalties garnered from radio airplay and the use of the Kingsmen version in movies and commercials. Paul Farhi, “'Louie, Louie'; Kingsmen Awarded Royalties,” Washington Post, November 10, 1998.

59 "Sample Licensing in the Music Industry," Chaos Webpage, http://www.cmm.com.au/legal/sample.htm.

60 Ibid

61 U.S. Constitution, Article I Section 8. 
others who wish to perform it publicly. ${ }^{62}$ The Copyright Act of 1976, a rewriting of the original Act, was written to promote "the broad public availability of literature, music, and the other arts." ${ }^{63}$ It gave holders of musical composition copyrights the exclusive right to reproduce the music, make a derivative work based on the copyrighted music, distribute the work publicly, perform the music publicly and display the work publicly. ${ }^{64}$ In 1989, the U.S. joined the Berne Convention for the Protection of Literary and Artistic Works, which allowed works to be legally copyrighted without explicit notice on each copy.

\subsection{German Copyright Legislation for Music}

Artistic freedom ${ }^{65}$ and guarantee on property \& the right of inheritance $^{66}$ are enshrined in German Basic Law (Grundgesetz, GG). According to German Copyright Act 1965, Article 85, 'the producer of an audio recording shall have the exclusive right to reproduce and distribute the recording. If the audio recording has been produced by an enterprise, the owner of the enterprise shall be deemed the producer. Article 24, of the same Act says that 'An independent work created by free use of the work of another person may be published and exploited without the consent of the author of the used work but shall not apply to the use of a musical work where a melody has been recognizably borrowed from the work and used as a basis for a new work.'

\subsection{The Core U.S. Cases}

The U.S., the cradle of sampling, also saw the birth of the first music sampling litigation cases. The mentioned cases in this sub chapter is very important to understand the gradual development of the US law of sampling. Only the most important cases are discussed here which played the role to formulate the sampling legal system in the US. Through evaluating the facts in issue and the norms formulated by the US courts, a stable and efficient picture of confronting sampling can be drawn. In addition, this can be a tool of comparison for a better understanding of the issue.

In 1991, federal court case Grand Upright Music Ltd v. Warner Bros. Records ${ }^{67}$, the judge began his sentence with a biblical quote - "thou shalt not steal." He then granted an injunction to Grand Upright Music to prevent

62 William H. O’Dowd, "Note: The Need For a Public Performance Right in Sound Recordings," 31 Harvard Journal on Legislation 249.

63 Twentieth Century Music Corp. v. Aiken, 422 U.S. 151, 156 (1975). Hampel, S. (1992).

64 gopher://wiretap.spies.com/00/Library/Article/Rights/copyrigh.mus.

65 Art. 5 para. 3, Basic Law for the Federal Republic of Germany

66 Article 14 (1), Ibid

67780 F. Supp. 182 (SDNY 1991) 
further copyright infringement of the Gilbert O’Sullivan song "Alone Again” by Warner Bros. The quote was symbolic of the way in which U.S. courts would thereafter deal with sampling. The decision changed the modus operandi of the hip-hop music industry which, from then on, had to ensure all music sampling was preapproved by copyright owners.

2005 changed all the plots dramatically with the emergence of Bright Line rule prejudicing more stable and friendly practices of sampling by the courts. The court prohibited sampling without the consent of the right holder at all. According to the academicians, lawyers and the critics of the US, the ruling in Bridgeport Music, Inc. v. Dimension Films, ${ }^{68}$ was one of the mistakes of the court. In fact, different courts in many states including the ninth circuit rejected the decision explicitly or declined to apply it. ${ }^{69}$

Fortunately, in TufAmerica ruling of 2014, ${ }^{70}$ erudite ruling again found its track back. The plaintiff in the case was the rights holder of the sound recording and musical work entitled 'Hook \& Sling Part I', which was recorded by Eddie Bo and the Soul Finders. The defendant was a company that produced a sound recording called 'Run This Town', which was performed by Jay-Z, Rihanna and Kanye West. The plaintiff alleged an unauthorized sampling of the succinct exclamation "oh" of Eddie Bo by the defendant, who subsequently looped ${ }^{71}$ it 42 times in its own sound recording.

Plaintiff failed to qualify both qualitative and quantitative test of sampling. ${ }^{72}$ The court said, the sample was restricted to the background of the song Run This Town and an untrained ear would have found it difficult to detect. ${ }^{73}$ So the district court founded the sampled snippet as merely de minimis, therefore, any further examination would render the qualitative significance of the sample meaningless. ${ }^{74}$

In VMG Salsoul, case of $2016^{75}$, the plaintiff alleged that Shep Pettibone, the producer of the song 'Vogue', performed by Louise Ciccone a.k.a. Madonna, sampled without authorization two horn hits, totaling a sample of less than a second, from the song 'Love Break' also produced by him. The defendant sampled the "single" horn hit once, the "double" horn hit

68410 F.3d 792 (6th Cir. 2005)

69 See string-cite in VMG Salsoul v. Ciccone, 9th Circuit June 2, 2016, at p.30 of the PDF slip opinion.

70 TufAmerica, Inc., v. WB Music Corp., et. al., 67 F.Supp.3d 590 (2014).

71 Looping means the repetition (and in various instances the production of a musical base) of a sampled portion in the derivative works by way of alteration, if any. See Amanda Webber: Digital Sampling and the Legal Implications of its Use after Bridgeport, Saint John's Journal of Legal Commentary, 2007: p. 380-382.

72 Ibid. at 597.

73 Ibid. at 598.

74 Ibid.

75824 F.3d 871 (2016) 
three times and the "breakdown" version once in his own work. ${ }^{76}$ While rejecting this argument the Ninth Circuit reasoned that no infringement had occurred due to the de minimis use. Applying this to the VMG Salsoul case, it seems highly unlikely that an average audience would be able to discern the part of the horn hit of 'Love Break' in 'Vogue'.77 As such, the court followed the same reasoning as Newton ${ }^{78}$ and described the sample used from the original sound recording as minimal. ${ }^{79}$ The court departed from Bridgeport ${ }^{80}$ by implementing a multi-faceted argument. It highlighted that the de minimis rule has its roots in decisions dating back to the mid-19th century, thus it is unassailably embedded in the system of U.S. copyright law ${ }^{.81}$

Concerning Fair Use disposal case ${ }^{82}$, Drake, along with various associated record labels and music publishers, pulled off an impressive achievement by convincing a judge that his song "Pound Cake/Paris Morton Music," off the 2013 album Nothing Was the Same, fairly sampled a 1982 spoken-word recording, "Jimmy Smith Rap," and that there is no liability for copyright infringement. When it comes to documentaries and less abstract art forms, judges can parse meaning and figure out whether use of copyrighted material is transformative. This "Pound Cake" case did not have the element but U.S. District Court judge William H. Pauley III has taken the unusual step of addressing Drake's purpose in sampling in 2017.

The conclusion is that the US has undergone through generations of music sampling. At first, it dealt issues with the substantial similarity, the de minimis rule and the fair use doctrine. However, the practice was dropped in 2005 by bright line ruling though the court tried to simplify the then present and the future situation. The existing last generation got its probity back by justifying sampling in various means.

\subsection{German cases and reference to ECJ}

German copyright law also proved sufficient in terms of overcoming situation. In reality, German copyright legislation is a clear reflection of EU treaties which deals with strong protection of copyright law and the fundamental freedoms which are enshrined in the Charter of Fundamental Rights. But the real dispute is between protection and freedom, especially

76 For the fact of the case see VMG Salsoul, LLC, v. Madonna Louise Ciccone, et. al., 824 F.3d 871 (2016), p. 875-876.

77 VMG Salsoul v. Madonna (2016), p. 878-879.

78 Newton v. Diamond, 349 F.3d 591 (9th Cir. 2003)

79 Ibid to 37 at 879-880.

80 Bridgeport Music, Inc. v. Dimension Films, 410 F.3d 792 (6th Cir. 2005)

81 Ibid to 43 at 880-881.

82 Estate of James Oscar Smith, et ano. vs. Cash Money Records, Inc., et all. 1:14-cv-02703WHP, 30.05.2017 
when both have been argued against each other in the same lawsuit while the same instrument confirms these rights to different parties. Now it is the challenge for the ECJ to prioritise them, to put it differently, which right should prevail over the other.

In the Goldrapper case83, the $B G H$ partly overruled its own decision rendered in the earlier Metall auf Metall $\mathrm{II}^{84}$ case. In this case, the German rapper Bushido sampled portions totaling approximately 10 seconds of the French gothic metal group, Dark Sanctuary. He then used and looped them in 13 of his own sound recordings as background music. ${ }^{85}$ There the $B G H$ held that sampling musical snippets („Tonfetzen”) is subject to authorization. In Goldrapper, however, the $B G H$ held that infringement may occur only if the music sample is the result of a creative activity and that the used portion reaches the minimum threshold relating to the protection of intellectual creations. $^{86}$

In 1977, the German band Kraftwerk released a song called "Metall auf Metall," which they also produced. The defendants sampled a sequence of two seconds from "Metall auf Metall," put the sample on a loop and used it as the continuous rhythmic layer for a rap song. The Federal Supreme Court ruled that this act constituted an infringement of Kraftwerk's copyright-related right as producers of the original sound recording (sec. 85 para. 1 of the German Copyright Act). The "free use" exception (sec. 24 para. 1 of the German Copyright Act) was not considered applicable in this case because, essentially, it would not have been unreasonably cumbersome for the defendants to produce a "sound-alike" rhythm sequence.

The Federal Constitutional Court held that where the act of sampling only slightly limited the possibilities of exploitation, the interests of the holder of a copyright (or a related right of the phonogram producer) may have to cede in favour of artistic freedom. ${ }^{87}$ "The economic value of the original sound was therefore not diminished," the court said, adding that banning sampling would in effect spell the end of some music styles. ${ }^{88}$ "The hip-hop music style lives by using such sound sequences and would not survive if it were banned." ${ }^{89}$

83 BGH Urt. v. 16.04.2015 (I ZR 225/12) - Goldrapper, Gewerblicher Rechtsschutz und Urheberrecht, Issue No. 12/2015: 1189-1198. See further Clark, Birgit (2015).

84 IZR 182/11

85 Mezei, Péter (2017)

86 BGH Urt. v. 16.04.2015 (I ZR 225/12) - Goldrapper, Gewerblicher Rechtsschutz und Urheberrecht, Issue No. 12/2015: 1189-1198. See further Clark, Birgit (2015).

87 https://www.lexology.com/library/detail.aspx?g=21e269d8-dab0-431e-

97b1-3a8493b507cc

88 https://www.theguardian.com/music/2016/may/31/kraftwerk-lose-legal-

battle-over-their-music-being-sampled

89https://uk.reuters.com/article/us-germany-music-sampling/german-court-allows-music-

sampling-for-hip-hop-producer-idUKKCNOYM1JQ 
Only in cases of a high degree of similarity between the songs at issue could one actually presume that the new work will compete with the original work.

\section{Reference to ECJ}

Whilst German law acknowledges the economic rights of sound recording producers, they cannot result in the creation of monopolies. This means on the one hand, that rights holders are granted every possible means of utilization. ${ }^{90}$ Yet, on the other hand, these rights may be restricted by the legislator at any time. ${ }^{91}$ The question of which rights and interests take priority in an actual case is subject to a court's discretion. ${ }^{92}$ The German Federal Supreme Court (BGH) asks CJEU for guidance respectively, on:

- To what extent EU copyright allows sampling,

What role the rights granted by the Charter of Fundamental Rights of the European Union plays: in particular, what is the relationship between copyright protection (Article 17(2)) and freedom of the arts (Article 13)? ${ }^{93}$

The CJEU's decision will be eagerly anticipated as it is not only relevant for the present case at hand; furthermore, it will affect the entire music industry and determine to what extent sample-based music is still possible in the future. If protection of copyright wins then of course, sampling would be impossible in the future without permission. Oppositely, if artistic freedom wins then the law might tolerate sampling to reasonable extent.

\section{Analysis and Conclusion}

\subsection{Comparative Analysis of US and German Approach}

Both U.S. and German courts have applied this potential opportunity for exemption in a restrictive way. ${ }^{94}$ The U.S. Court of Appeals for the Sixth Circuit in Nashville held that a two-second sample infringed the sound recordings copyright. The three-judge panel in Bridgeport Music Inc. et al. $v$. Dimension Films et al. ${ }^{95}$ created a "new rule" in federal copyright law which was criticized heavily by lawyers and other industries including the RIAA. ${ }^{96}$

In light of the most recent developments, it is plausible that the Supreme Court ruled against Bridgeport for several reasons. First, the validity

\footnotetext{
90 Fabian Böttger - Birgit Clark: German Constitutional Court decides that artistic freedom may prevail over copyright expolitation rights ('Metall auf Metall'), Journal of Intellectual Property Law \& Practice, Issue No. 11/2016: p. 813; Mimler, supra note 10 at 123.

91 Metall auf Metall III (2016), 1 BvR 1585/13, p. 691-692.

92 Ibid. at 692.

93 https://www.techdirt.com/articles/20170606/06084737524/two-big-

copyright-cases-sent-to-top-eu-court-one-sampling-other-freedom-press.html

94 Simon, Apel (2010).

95410 F.3d 792 (6th Cir. 2005)

96 https://en.wikipedia.org/wiki/Legal_issues_surrounding_music_sampling
} 
and importance of the de minimis standard is unquestionable and it has been used by the U.S. judiciary for decades ${ }^{97}$ Second, the U.S. Supreme Court does not favour the application of bright line rules in intellectual property law. Daniel J. Gervais noted that "at least five times in recent years, the Supreme Court has told the Federal Circuit not to adopt bright line tests. So that's probably a sign the Supreme Court would support the 9th Circuit's interpretation". ${ }^{98}$ The Ninth Circuit emphasized that Section 114(b) of the USCA is the explicit limit of the copyright holder's exclusive rights. Therefore, extending the rule in an implicit way for the benefit of the copyright holder is rather inappropriate ${ }^{99}$ and it is not even supported by the preparatory documents of the USCA. ${ }^{100}$

To determine between fair use and actual copyright infringement, judges and juries look at a variety of factors, such as: the length of the use, the purpose of the use, and more generally, whether the use is "transformative." A transformative use basically refers to a quotation in which you've changed the context or altered the original sufficiently to transform it into something new. This concept has played an increasingly important role in fair use decisions of the past 20 years by courts. However, German courts only used this transformative use in the name of free use principle which consists only a portion of the US fair use.

\subsection{Applicability of de minimis and Fair Use in the EU}

Predicting the ECJ's ruling is far from straightforward. On the one hand, the ECJ is faced with the need to balance fundamental rights in numerous cases. ${ }^{101}$ It cannot be said that the US fair use and de minimis are revolutionary reformatories but at least they have been proved to be efficacious. German courts have already shown the functionality of the US fair use in the name of free use and de minimis within the scope of European legal framework. If the ECJ tries to implement these, there are already room for application. Indeed, the need for such balance is indirectly confirmed by the Charter of Fundamental Rights of the European Union. According to Article 52 on the principle of proportionality "any limitation on the exercise of the rights and freedoms recognised by this Charter must be provided for by law

97 Inest, Andrew (2006).

98 Seidenberg, Steven (2016).

99 "The exclusive rights of the owner of copyright in a sound recording under clauses (1) and (2) of section 106 do not extend to the making or duplication of another sound recording that consists entirely of an independent fixation of other sounds, even though such sounds imitate or simulate those in the copyrighted sound recording”. See the third phrase of §114(b) of the USCA.

100 Ibid. at 883-884.

101 available via http://ec.europa.eu/justice/fundamental-rights/charter/application/index_en. htm. 
and respect the essence of those rights and freedoms. Subject to the principle, limitations may be made only if they are necessary and genuinely meet objectives of general interest recognised by the Union or the need to protect the rights and freedoms of others."

Again, intellectual property rights deserve protection under Article 17(2) of the Charter of Fundamental Rights of the European Union. This form of protection is clearly codified by the InfoSoc Directive that speaks of the high level of protection of copyrights. ${ }^{102}$ At the same time, intellectual property rights are not absolute, and their exercise should be subject to the effective functioning of other fundamental rights. For example, in the two $S A B A M$ preliminary rulings the ECJ stressed that striking a balance between the different fundamental rights is a priority of EU law. ${ }^{103}$ Should the ECJ decide not to dig into a fundamental rights discourse, the InfoSoc Directive still offers enough space to treat sampling as an acceptable practice under EU law. Undoubtedly, sampling is a form of reproduction and that right has been harmonized by the EU. ${ }^{104}$ Further, no specific limitation or exception has been dedicated to sampling in the InfoSoc Directive ${ }^{105}$ and any new limitation or exception would be solely acceptable under the "grandfather clause" if its significance and economic impact is negligible. ${ }^{106}$

However, it would be highly problematic for the freedom of the arts, if minimal uses of samples were foreclosed by the ECJ. As freedom of the arts is equally protected by the Charter of Fundamental Rights of the European Union, the above syllogism along with de minimis and Fair Use of US courts, seems to be fully applicable, in balancing the competing interests between composers, sound recording producers and secondary creators of samples.

Duhanic's thoughts may serve as an apt conclusion to the aforementioned analysis. She noted that "the historical development of the German Copyright Act has proven that were always new techniques that appeared, and the Copyright Act had to keep up with the zeitgeist”. ${ }^{107}$ In the past thirty or forty years, sampling has become part of the zeitgeist. ${ }^{108}$

102 See Directive 2001/29/EC of the European Parliament and of the Council of 22 May 2001 on the harmonisation of certain aspects of copyright and related rights in the information society, recital 9.

103 Case C-70/10, ECLI:EU:C:2011:771, para. 46; Case C-360/10, ECLI:EU:C:2012:85, para. 44.

104 Article 2, InfoSoc Directive.

105 Compare to ibid. Article 5.

106 "Use in certain other cases of minor importance where exceptions or limitations already exist under national law, provided that they only concern analogue uses and do not affect the free circulation of goods and services within the Community, without prejudice to the other exceptions and limitations contained in this Article.” See InfoSoc Directive Article 5(3)(o).

107 Duhanic, supra note 7 at 1016.

108 Ibid 


\subsection{Conclusion}

Digital sampling is a good example for technological progress that does not fit into the traditional European author's rights regimes. That is because firstly, the Continental European countries rarely have any copyright clause in their constitutions (contrary to the US Constitution, Art.1. par. 8. cl. 8.); secondly, no stable practice regarding the "de minimis" standards, however, InfoSoc Directive Recital 35 says: in certain situations where the prejudice to the right holder would be minimal, no obligation for payment may arise. The BVerfG ruling enjoyed a positive reception from German academia. ${ }^{109}$ Commentators agreed that the BVerfG may aid the survival of sampling ${ }^{110}$, a specific manifestation of postmodern culture, which has become indispensable in various musical genres, and through this has promoted creativity and genre diversity, which arguably helps indirectly safeguard the jobs of numerous artists. ${ }^{111}$ Observers also claimed that the decision may help steer the legal qualification of other manifestations of postmodern culture or pop-art (collage, appropriation of art, mash-up, fanfiction, etc.) towards a more positive direction. ${ }^{112}$ The defenses are important indicators that sampling is not specifically prohibited nor embraced in the Constitution, Copyright Act and court decisions, but rather could be allowed or restricted with full legal legitimacy depending on whether it is found to be consistent with the underlying purposes of the Constitutional clause and the implementing legislation.

Sampling is particularly common in modern hip-hop and electronic music. The BVerfG held that the case giving rise to the aforementioned judgment was about a clash between legal provisions concerning sound recording producers pursuant to the first sentence of Section 85(1) of the UhrG and the right for free use under Section 24 of the UhrG. Nevertheless, these rights are based on Article 14(1) of the German Constitution on property interests and on the first sentence of Article 5(3) on the fundamental right of artistic expression, respectively. ${ }^{113}$ It is even more concerning when the clash is between two provisions of the CFR and the ECJ has been tasked to prioritize among copyright protection and freedom of art within the same charter. Lights have been shaded on some approaches taken by the US which seems to be most balanced until now specially when the task is to draw a balance between

109 Ibid. at 606-612; Leistner, supra note 40 at 772-777; Sven Schonhofen: Sechs Urteile über zwei Sekunden, und kein Ende in Sicht: Die 'Sampling'-Entscheidung des BVerfG, Gewerblicher Rechtsschutz und Urheberrecht-Praxis, Issue No. 13/2016: p. 277-280. 277280; Duhanic, supra note 7 at 1013-1016.

110 Podszun, supra note 46 at 608.

111 Duhanic, supra note 7 at 1011.

112 Podszun, supra note 46 at 609; Böttger - Clark, supra note 42 at 813.

113 Metall auf Metall III (2016), p. 691. See also Duhanic, supra note 7 at 1011. 
right and lawful use. It is undoubtful that the EU legal system provides enough room to apply the US fair use and de minimis, evolved in the US court rooms, which proved to not only serve the US legal system for more than 20 years but also, they became the tool of striking the balance which might be applied by the judges of the ECJ too.

One thing is sure regardless of the outcome: Kraftwerk, the pioneer of modern electronic music, will again have a huge impact on the music industry. ${ }^{114}$

\section{References:}

1. United States Constitution 1787

2. The Copyright Act of 1976

3. Basic Law for the Federal Republic of Germany

4. German Copyright Act 1965

5. Lessig, L. (2008). Remix: Making Art and Commerce Thrive in the Hybrid Economy. New York: Penguin Press, p. 104.

6. Fellmeth, A and Horwitz, M. (2009). Guide to Latin in International Law. USA: Oxford University Press.

7. Passman, Donald S. (1997). All You Need to Know About the Music Business, New York: Simon And Schuster, p. 220.

8. Miller aka DJ Spooky, Paul D, Doctorow, Cory; Reich, Steve (2008). Sound Unbound: Sampling Digital Music and Culture. Cambridge, Massachusetts: The MIT Press. ISBN 978-0-262-63363-5.

9. Wilson, S. R. (2002). Music Sampling Lawsuits: Does Looping Music Samples Defeat the De Minimis Defense, Journal of High Technology Law (p. 136, 137). ISSN 1536-7983

10. Christiansson, J. (1995). Upphovsrätt och närliggande aspekter musiksamling, Omarbetningar och sampling. Stockholm: Juristförlaget.

11. Hampel, S. (1992). "Note: Are Samplers Getting a Bum Rap?: Copyright Infringement of Technological Creativity?” (559), University of Illinois Law Review.

12. Simon, Apel (2010). Bridgeport Music, Inc. v. Dimension Films (USA), Metall auf Metall (Germany) and Digital Sound Sampling 'Bright Line Rules'? (3) Zeitschrift für Geistiges Eigentum / Intellectual Property Journal.

13. Neimann, F and Mackert, L. (2013). Limits of sampling sound recordings: the German Federal Court of Justice’s Metall auf Metall I

114 https://www.lexology.com/library/detail.aspx?g=bdd9d631-42da-4670-94a9-45641242 3d62 
\& II holdings in light of the US jurisprudence on digital sampling. (6) E.I.P.R. 35 (pp. 356-360).

14. Tracy, Reilly (2012). Good Fences Make Good Neighboring Rights: The German Federal Supreme Court Rules on the Digital Sampling of Sound Recordings in Metall auf Metall, Minnesota Journal of Law, Science \& Technology (p. 163-199).

15. Blessing, D. S. (2004). Who Speaks Latin Anymore? Translating De Minimis Use for Application To Music Copyright Infringement and Sampling, (45), Wm. \& Mary L. Rev. 2399 (p. 2410)

16. Sykes, J. (2006). Copyright - the de minimis defense in copyright infringement actions involving music sampling, (36), U. Mem. l. L. Rev. 749, p. 763.

17. Seidenberg, Steven (2016). US Perspectives: US Courts Split on Legality of Music Sampling, Intellectual Property Watch.

18. Inest, Andrew (2006). A Theory of De Minimis and a Proposal for Its Application in Copyright, Berkeley Technology Law Journal (pp. 945995).

19. Clark, Birgit, (2015). Goldrapper: no copyright protection for delyricized samples used as looped background for a rap track? (11), Journal of Intellectual Property Law and Practice (pp. 816-817).

20. Mezei, Peter (2018). De Minimis and Artistic Freedom: Sampling on the Right Track? (139), Zeszty Naukowe Uniwersytetu Jagiellonskiego - Prace z Prawa Wlasnosci Intelektualnej (Jagiellonian University Intellectual Property Law Review), (pp. 56-67)

21. Metall auf Metall III (2016). p. 691. See also Duhanic, supra note 7 at 1011.

22. Queen Mary Journal of Intellectual Property, Issue No. 1/2017: p. 119122.

23. Journal of the Copyright Society, Vol. 56, p. 1017, 2009

24. Metall auf Metall, Kraftwerk, et al. v. Moses Pelham, et al. Decision of the German Supreme Court, 20th of November 2008, No. I ZR 112/06.

25. Metall auf Metall III (2016), 1 BvR 1585/13

26. Grand Upright Music Ltd v. Warner Bros. Records, 780 F. Supp. 182 (SDNY 1991)

27. Bridgeport Music Inc. et al. v. Dimension Films et al., 410 F.3d 792 (6th Cir. 2005)

28. TufAmerica, Inc., v. WB Music Corp., et. al., 67 F.Supp.3d 590 (2014)

29. VMG Salsoul, LLC, v. Madonna Louise Ciccone, et. al., 824 F.3d 871 (2016)

30. http://smallbusiness.chron.com/sampling-important-business80416.html, collected on 06.12.2017 
31. https://www.lexology.com/library/detail.aspx?g=bdd9d631-42da4670-94a9-456412423d62, collected on 07.12.2017

32. https://en.wikipedia.org/wiki/Legal_issues_surrounding_music_samp ling, collected on 07.12.2017

33. https://www.theguardian.com/music/2016/may/31/kraftwerk-loselegal-battle-over-their-music-being-sampled, Tuesday, 31 May '16, 16.20 BST, collected on 07.12.2017

34. https://uk.reuters.com/article/us-germany-music-sampling/germancourt-allows-music-sampling-for-hip-hop-produceridUKKCN0YM1JQ, May 31, 2016 / 4:01 PM / 2 years ago, collected on 07.12.2017

35. https://cyber.harvard.edu/fallsem98/final_papers/Tada.html, Yuriko Tada: The Internet and Musical Copyright Law, collected on 07.12.2017 